\title{
SEC16A Gene
}

National Cancer Institute

\section{Source}

National Cancer Institute. SEC16A Gene. NCI Thesaurus. Code C101472.

This gene is involved in intracellular protein transport. 